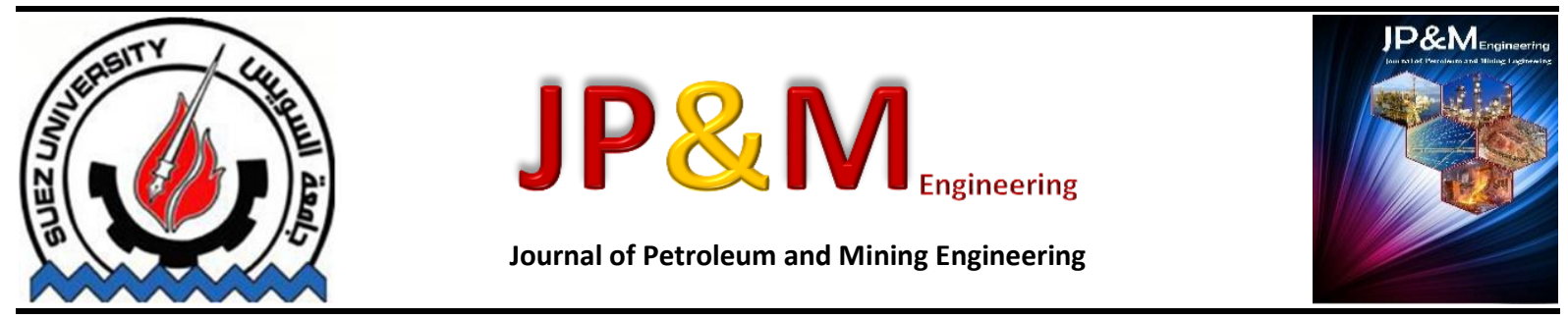

\title{
The Optimum Types and Characteristics of Drilling Fluids Used During Drilling in The Egyption Westren Desert
}

\author{
A. A. Elgibaly ${ }^{a}$, M. S. Farahat ${ }^{a}$, M. M. Abd El Nabbi ${ }^{b}$ \\ ${ }^{a}$ Faculty of Petroleum and Mining Engineering, Suez University, Suez, Egypt \\ ${ }^{b}$ Baker Hughes Inc., Egypt
}

\section{Keywords}

Wellbore stability; stuck pipe; pack off; water base drilling fluids; oil base drilling fluids.

\begin{abstract}
In this study, the factors that affect the selection of the types and characteristics of drilling fluids that were used while drilling nine wells in the Egyptian Western Desert were investigated. This study proves that the selection of drilling fluid type is not only based on the applications of drilling fluids, cost of drilling fluid or previous experience but also on other factors combined together such as geology of the area, potential problems for each section, make up base fluids availability, waste management techniques, environmental regulations, rig and drilling equipments and drilling data. In this study also, the evaluation of the designed characteristics of the selected types of drilling fluids was made to achieve the required functions such as good hole cleaning, well control, hole stability and to reduce lost circulation problem.
\end{abstract}

\section{Introduction}

A drilling fluid is defined as a pre- designed fluid which is circulated through a well in order to perform certain functions which can be achieved through the suitable choice of mud type and the day to day maintenance of the mud properties using the right additives[1,2]. It mainly consists of [3-5]:

1. The Liquid Phase,

2. Reactive Solids,

3. Dissolved Solids, and

4. Inert Solids.

Drilling fluids had been classified according to the type of base fluids to:

1. Pneumatic or Compressible Fluids,

2. Water Base Fluids,

3. Oil Base Fluids, and

4. Synthetic Base Fluids.

Galal, M.[6] stated that the correctly selected and engineered drilling fluid plays a significant role in delivering a high quality wellbore. This only can be achieved by an appropriately designed drilling fluid that must be tailored to satisfy many diverse parameters.

The Considerations that affect the selection of drilling fluids to meet specific conditions are[6-8]:
1. Application,

2. Geology,

3. Makeup Base Fluids,

4. Potential Problems,

5. Rig/Drilling Equipment,

6. Contamination,

7. Drilling Data,

8. Environmental Regulation,

9. Disposal \& Available Techniques for Waste Management, and

10. Economics.

Once the type of drilling fluid is selected using the above considerations, the drilling fluid characteristics should be designed. These characteristics could be listed as follows $[9,10]$ :

1. Drilling Fluid Density,

2. Drilling Fluid Viscosity and Rheology,

3. Gel Strength,

4. Fluid Filtration Properties, and

5. Chemical Properties. 


\section{Results and Discussions}

\section{Field I}

This field is an exploratory field located in Abu Sannan Area in the Egyptian Western Desert. The formations names, types and litheology are listed in table 1.

Table 1 Formation Names and Litheology for Field I.

\begin{tabular}{|c|c|}
\hline Formation & Litheology \\
\hline Moghra & Sand, Shale and Limestone \\
\hline Dabaa & Shale \\
\hline Appollonia & Limestone and Shale \\
\hline Khoman & Chalky Limestone \\
\hline Abu Roash A & Shale and Limestone \\
\hline Abu Roash B & Limestone and Shale \\
\hline Abu Roash C & Shale and Limestone \\
\hline Abu Roash D & Limestone and Shale \\
\hline Abu Roash E & Shale and Limestone \\
\hline Abu Roash F & Limestone and Shale \\
\hline Abu Roash G & Shale and Limestone \\
\hline
\end{tabular}

Table 2 Drilling Fluids Types and Their Formulations for Field I.

\begin{tabular}{|c|c|}
\hline Bahariya & $\begin{array}{c}\text { Sandstone,Siltstone, } \\
\text { Limestone and Shale }\end{array}$ \\
\hline Kharita & Sandstone and Shale \\
\hline
\end{tabular}

Three wells were drilled in this area. Each well drilled in four sections started with 26 " as the surface holes and two intermediate intervals $171 \frac{1}{2}$ " and $12 \frac{1}{4}$ ", to avoid induced fracture in Appolonia formation by the mud weight that was used to drill through Dabaa formation, then the well is finished by $81 / 2$ " section as production hole. One sidetrack was drilled as 6" hole as a result of losing the original $81 / 2$ " section in one of these wells. Drilling fluids types were selected in this field based on drilling fluids applications, drilling fluids costs and previous experiences about the area. Spud mud was selected to drill loose sand in top holes such as $26^{\prime \prime}$ and $171 / 2$ " holes as it will provide thick filter cake against these formations. $\mathrm{NaCl} / 3-5 \% \mathrm{KCl}$ polymer mud was selected to drill intermediate and production sections such as the rest of $171 / 2$ " section, $12 \frac{1}{4} ", 8 \frac{1}{2}$ " and 6 " sections to inhibit shale formations presented in these sections. High performance water base drilling fluids were selected because of the problems that were encountered while drilling using $\mathrm{NaCl} / 3-5 \% \mathrm{KCl}$ polymer mud even after increasing $\mathrm{KCl}$ percentage from 3-5\% to 7- $8 \%$. Tables 2 and 3 list the drilling fluids compositions and properties while drilling in this field.

Many drilling problems related to the type of drilling fluids being used were encountered. Figures from 1 to 5 manifest the occurrence of problems in each section while drilling.

\begin{tabular}{|c|c|c|c|c|}
\hline \multicolumn{5}{|c|}{ Drilling Fluid Formulation } \\
\hline Product/concentration & $\begin{array}{l}\text { Spud } \\
\text { Mud }\end{array}$ & $\begin{array}{c}\text { Polymer Gel } \\
\text { Mud }\end{array}$ & $\begin{array}{c}\text { NaCl/3-5 \% KCl Polymer } \\
\text { Mud }\end{array}$ & HPWBDF \\
\hline Bentonite & $\begin{array}{c}25-30 \\
\text { ppb }\end{array}$ & $25-30 \mathrm{ppb}$ & - & - \\
\hline Caustic Soda & $\begin{array}{c}0.25-1.0 \\
\mathrm{ppb}\end{array}$ & $\begin{array}{c}0.25-1.0 \\
\mathrm{ppb}\end{array}$ & $0.25-1.0 \mathrm{ppb}$ & $0.5-1.0 \mathrm{ppb}$ \\
\hline Soda Ash & $\begin{array}{c}0.25-1.0 \\
\mathrm{ppb}\end{array}$ & $\begin{array}{c}0.25-1.0 \\
\mathrm{ppb}\end{array}$ & $0.25-1.0 \mathrm{ppb}$ & $0.5-1.0 \mathrm{ppb}$ \\
\hline Thinner & $\begin{array}{c}0.15-0.5 \\
\mathrm{ppb}\end{array}$ & $\begin{array}{c}0.15-0.5 \\
\mathrm{ppb}\end{array}$ & If needed & If needed \\
\hline Poly Anionic Cellulose LV & - & $1.0-3.0 \mathrm{ppb}$ & $1.0-3.0 \mathrm{ppb}$ & - \\
\hline Xanthan Gum & - & $\begin{array}{c}0.25-1.0 \\
\mathrm{ppb}\end{array}$ & $0.25-1.0 \mathrm{ppb}$ & $0.25-0.75 \mathrm{ppb}$ \\
\hline $\mathrm{KCl}$ & - & - & $3.0 \%-5.0 \%$ by wt\% & $3.0-5.0 \% / w t$ \\
\hline $\mathrm{NaCl}$ & - & - & $\begin{array}{c}\text { As needed to increase } \\
\text { mud Density }\end{array}$ & $\begin{array}{c}\text { As needed to increase } \\
\text { mud Density }\end{array}$ \\
\hline $\begin{array}{c}\text { Asphaltic Materials(Shale } \\
\text { Stabilizer) }\end{array}$ & - & - & $1.0-2.0 \mathrm{ppb}$ & $3.0-5.0 \mathrm{ppb}$ \\
\hline Starch & - & - & $3.0-5.0 \mathrm{ppb}$ & $2.0 \mathrm{ppb}$ \\
\hline HTHP Fluid Loss Reducer & - & - & - & $3.0-5.0 \mathrm{ppb}$ \\
\hline Polyamine & - & - & - & $3.0 \%$ by $\mathrm{V}$ \\
\hline $\begin{array}{c}\text { Sulfonated Materials for } \\
\text { HTHP }\end{array}$ & - & - & - & $3.0-5.0 \mathrm{ppb}$ \\
\hline $\mathrm{CaCO} 3$ & - & - & - & $5.0-10.0 \mathrm{ppb}$ \\
\hline
\end{tabular}




\begin{tabular}{|c|c|c|c|c|}
\hline $\begin{array}{c}\text { Co- Polymers for Shale } \\
\text { Inhibition }\end{array}$ & - & - & - & $2.0 \%$ by V \\
\hline Lubricants & - & - & - & $2.0 \%$ by V \\
\hline
\end{tabular}

Table 3 Drilling Fluids Properties for Each Section in Field I.

\begin{tabular}{|c|c|c|c|c|c|c|c|c|c|c|}
\hline \multirow{3}{*}{$\begin{array}{c}\text { Location/Field } \\
\text { Section Name } \\
\text { Property Name } \\
\end{array}$} & \multicolumn{10}{|c|}{ Abu Sannan Area/Field I } \\
\hline & \multicolumn{2}{|c|}{ 26" } & \multicolumn{2}{|c|}{$171 / 2 "$} & \multicolumn{2}{|c|}{$121 / 4^{\prime \prime}$} & \multicolumn{2}{|c|}{$81 / 2 "$} & \multicolumn{2}{|c|}{ 6" } \\
\hline & Min & Max & Min & Max & Min & Max & Min & Max & Min & $\operatorname{Max}$ \\
\hline Density, ppg & 8.6 & 8.8 & 8.7 & 10.5 & 8.8 & 10.5 & 99 & 11.5 & 11 & 12.2 \\
\hline Funnel Viscosity, sec/quart & 65 & 90 & 50 & 90 & 48 & 68 & 45 & 68 & 55 & 68 \\
\hline$P V, \quad c P$ & 11 & 14 & 12 & 19 & 9 & 34 & 14 & 34 & 26 & 34 \\
\hline YP, lbf/100ft ${ }^{2}$ & 27 & 34 & 19 & 35 & 14 & 50 & 17 & 46 & 22 & 30 \\
\hline $10 \mathrm{sec} / 10 \mathrm{~min}$ Gel, $\mathrm{lbf} / 100 \mathrm{ft}^{2}$ & $8 / 11$ & $17 / 23$ & $4 / 6$ & $17 / 23$ & $4 / 7$ & $14 / 18$ & $3 / 6$ & $11 / 15$ & $7 / 10$ & $9 / 15$ \\
\hline API/HTHP Filtrate, $c c / 30 \mathrm{~min}$ & $\mathrm{~N} / \mathrm{C}$ & $\mathrm{N} / \mathrm{C}$ & $3.0 /-$ & $\mathrm{N} / \mathrm{C}$ & 2.9/- & $\mathrm{N} / \mathrm{C}$ & $2.6 /-$ & $5 / 14.8$ & $2.6 /-$ & $3.2 /-$ \\
\hline API/HTHP Cake, in/32 & $2.0 /-$ & $2.0 /-$ & $0.5 /-$ & $2 /-$ & $0.5 /-$ & $2.0 /-$ & $0.5 /-$ & $1.0 / 2.0$ & $0.5 /-$ & $0.5 /-$ \\
\hline $\mathrm{pH}$ & 9 & 9.5 & 9 & 9.5 & 9 & 11 & 9 & 10.5 & 9 & 10 \\
\hline Total Chlorides, $\mathrm{mg} / \mathrm{l}$ & 600 & $9 \mathrm{~K}$ & 700 & 139 & $2 \mathrm{~K}$ & $175 \mathrm{~K}$ & $148 \mathrm{~K}$ & $184 \mathrm{~K}$ & $124 \mathrm{~K}$ & $148 \mathrm{~K}$ \\
\hline $\mathrm{KCl}, \quad w \%$ & - & - & - & 7 & 7 & 7 & 7 & 8 & 7 & 8 \\
\hline MBT, lb/bbl & 22.5 & 25 & 5 & 25 & 5 & 22.5 & 2.5 & 10 & 5 & 10 \\
\hline Retort Water, \% & 96 & 96 & 85 & 96 & 85 & 97 & 80 & 96 & - & - \\
\hline Retort Oil, \% & - & - & & & & & & & - & - \\
\hline Retort Solids, \% & 4 & 4 & 4 & 15 & 3 & 15 & 4 & 20 & - & - \\
\hline
\end{tabular}

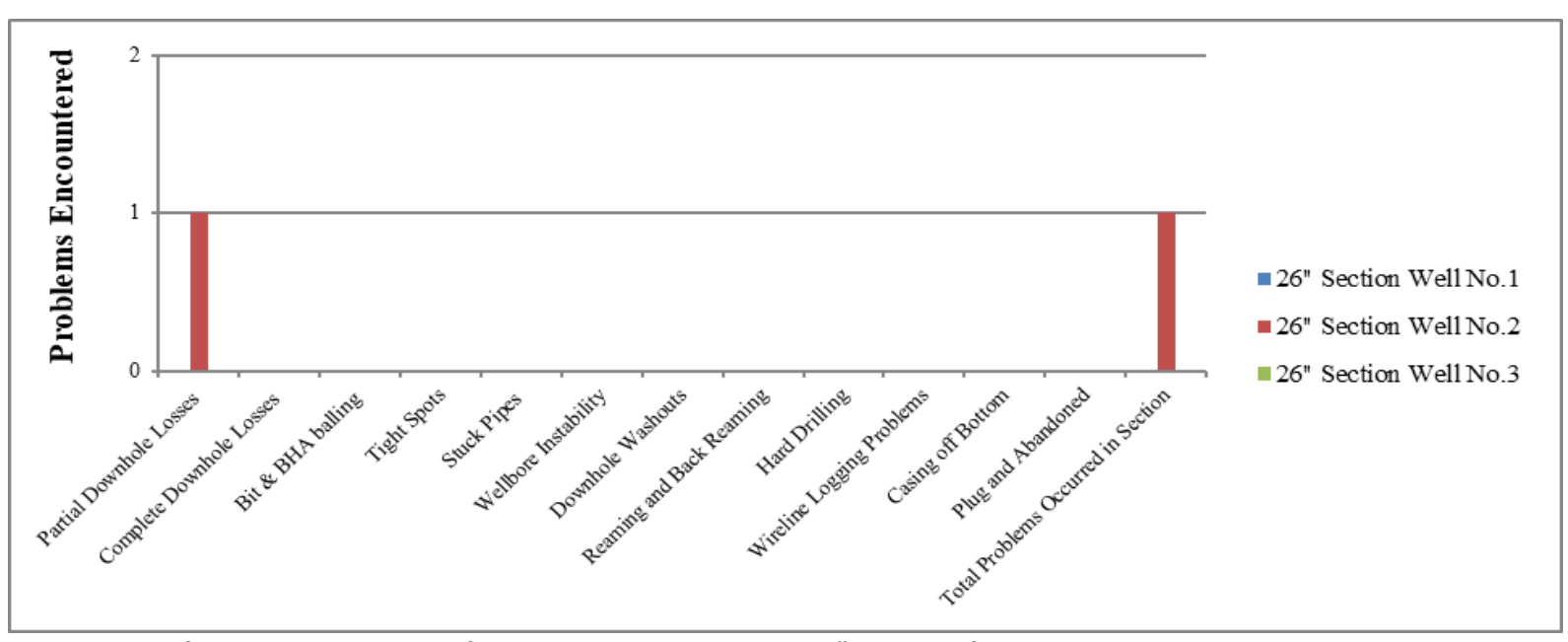

Figure 1 Manifests the Occurrence of the Expected Problems in 26" Sections for Wells No. 1, 2 and 3.

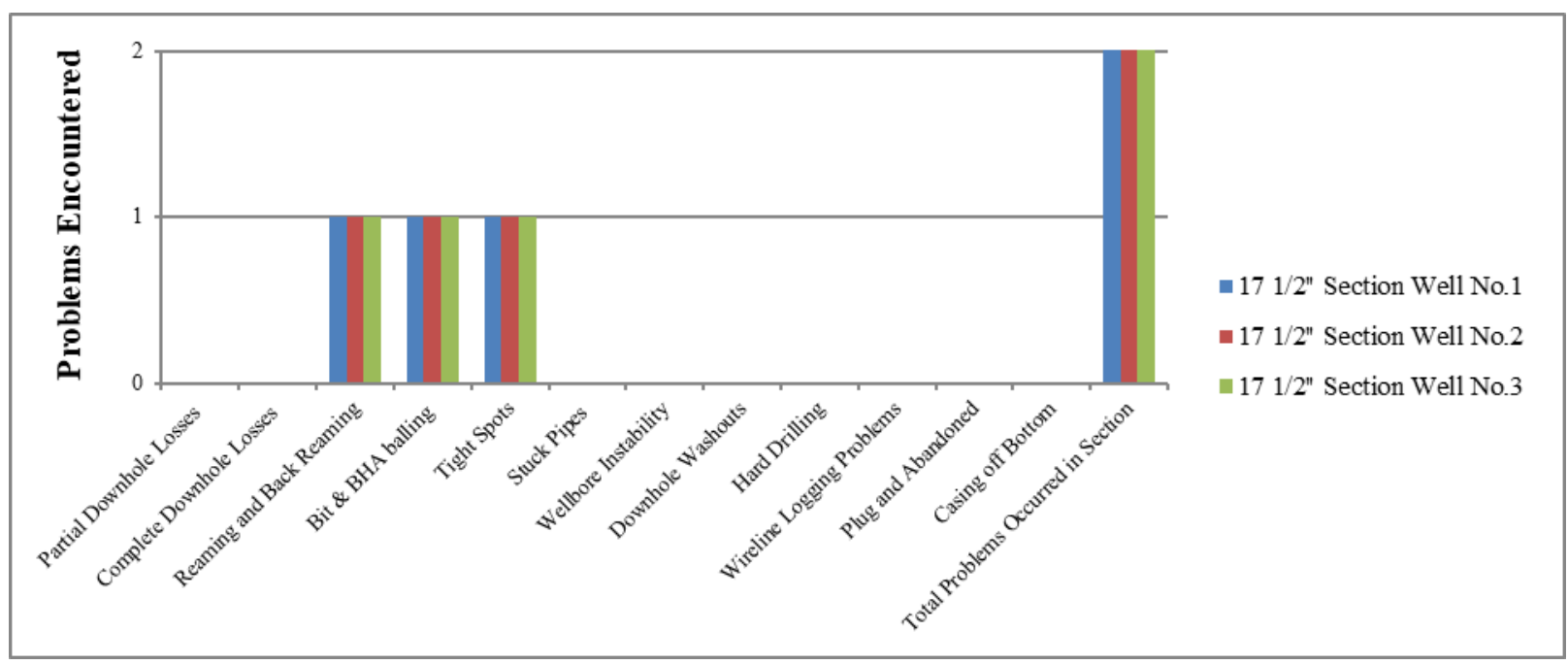

Figure 2 Manifests the Occurrence of the Expected Problems in 17 1/2" Sections in Field I. 


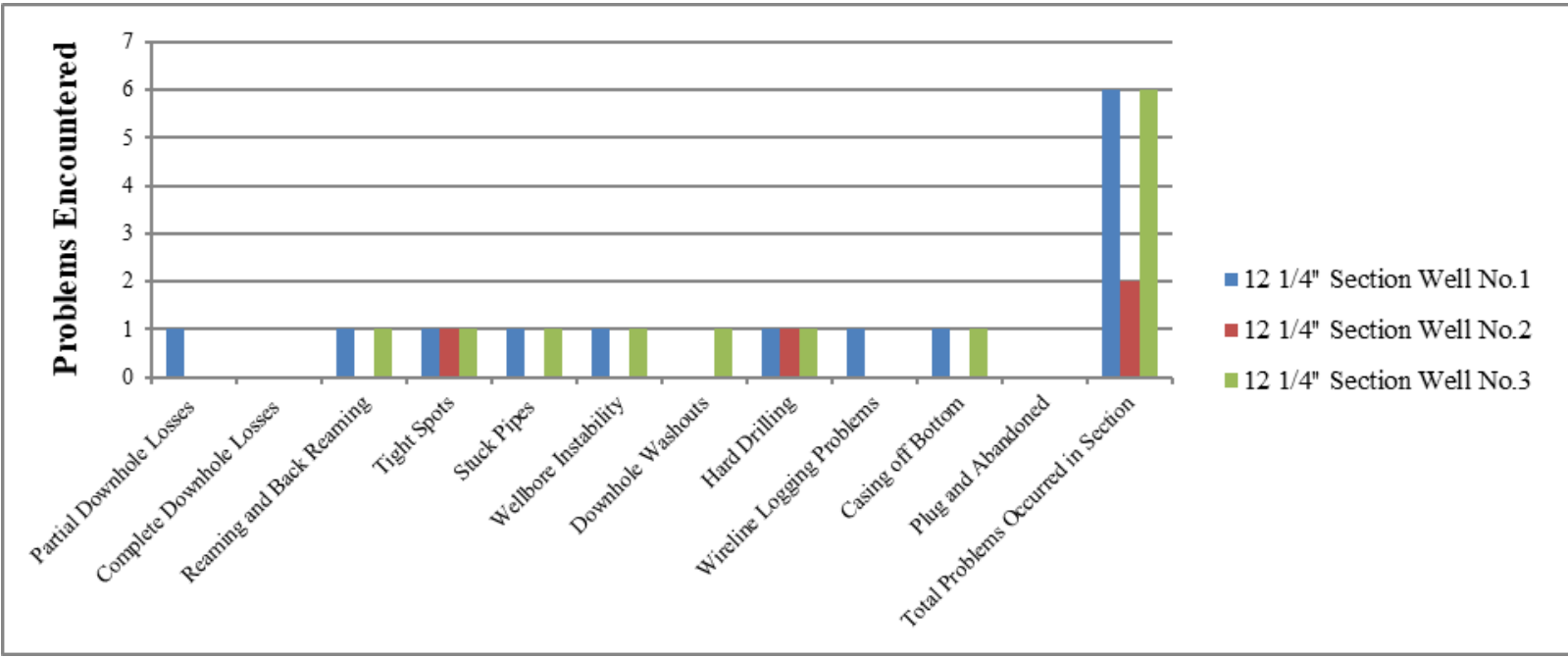

Figure 3 Manifests the Occurrence of the Expected Problems in 12 1/4" Sections in Field I.

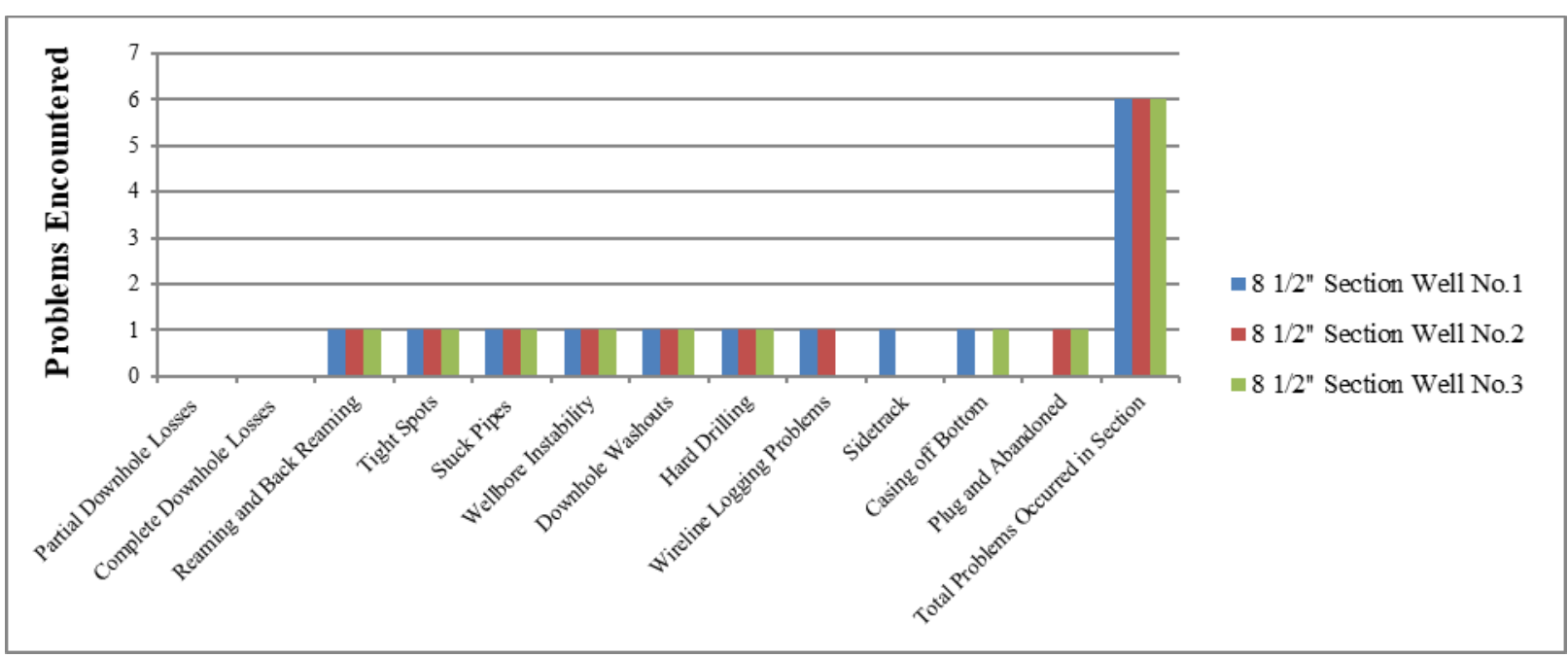

Figure 4 Manifests the Occurrence of the Expected Problems in 8 1/2" Sections in Field I.

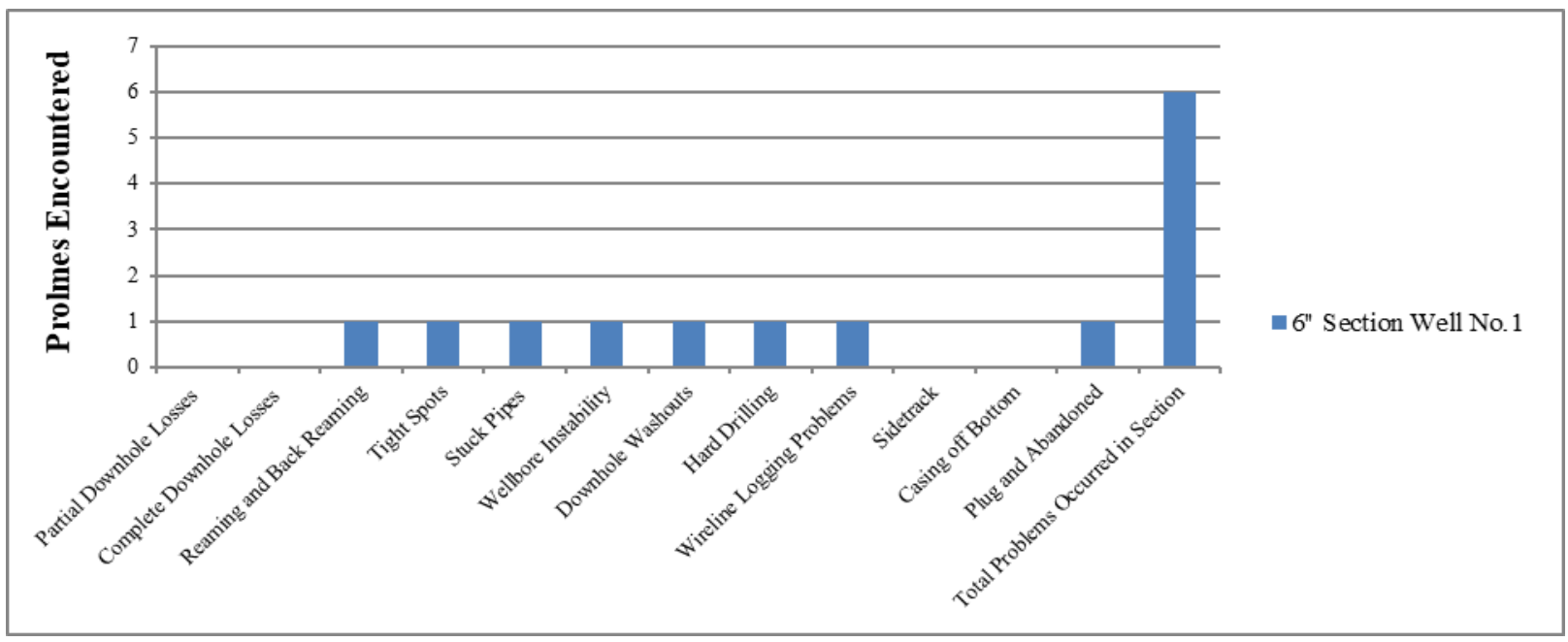

Figure 5 Manifests the Occurrence of the Expected Problems in 6" Section in Field I.

Many studies were suggested to be made such as shale analysis using $\mathrm{X}$-ray diffraction, linear swelling test, tri-axial test, and formation strength test on troublesome shale formations, but these studies were cancelled to save money. Only Shale analysis test was made using X-ray diffraction on Abu Roash E shale as shown in figure 6.

The test result showed that the amount of smectite is almost the same as kaolinite, and each one of them react differently with water base drilling fluids. Potassium ions cause many problems while drilling through kaolinitic shale[8], so that the type of drilling fluid should be changed to more reactive one, to drill this type of shale. Cost analysis was also made to study the effect of improper choice of drilling fluid type on well cost as shown in figures 7 and 8. 


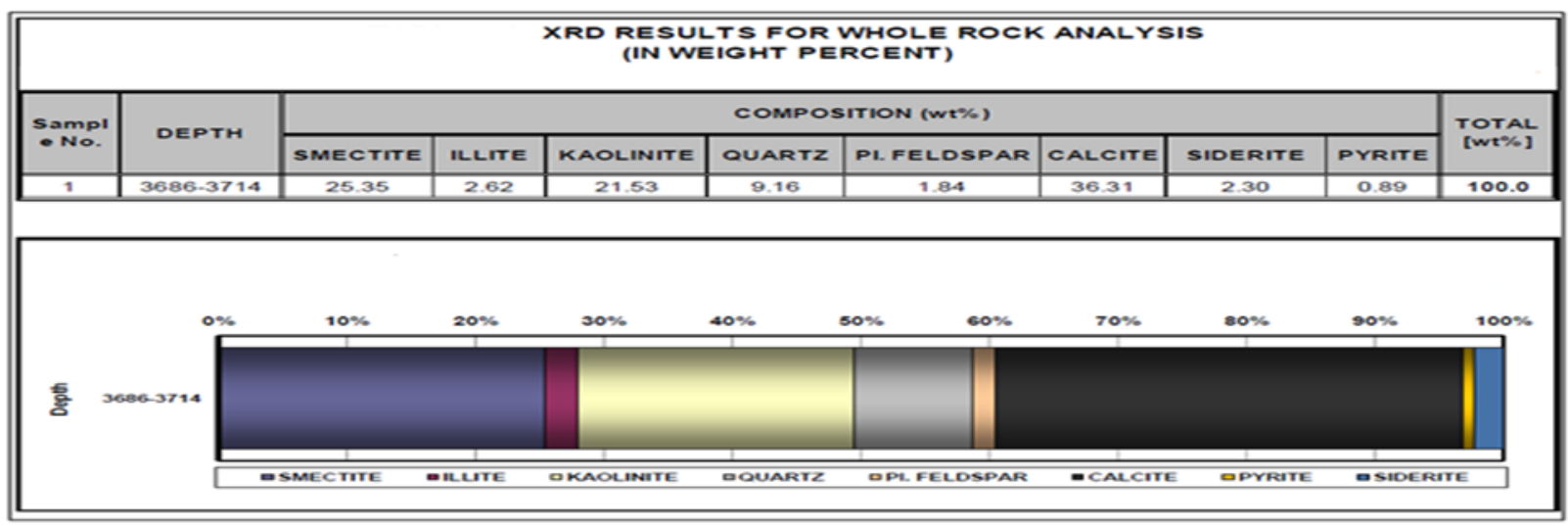

Figure 6 XRD Analysis in Weight Percent of Abu Roash E Interbedded Shale.

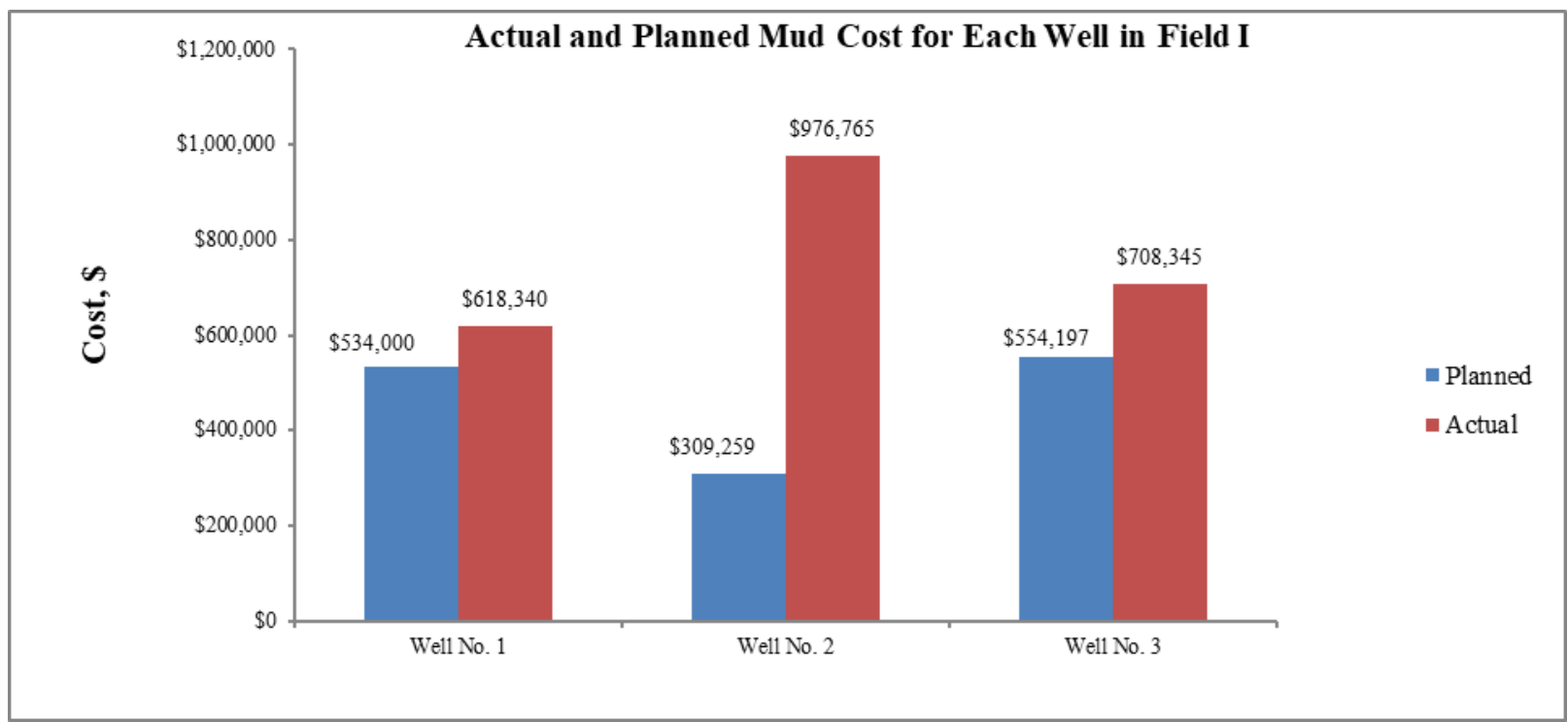

Figure 7 Comparison between Actual and Planned Mud Cost in Field I.

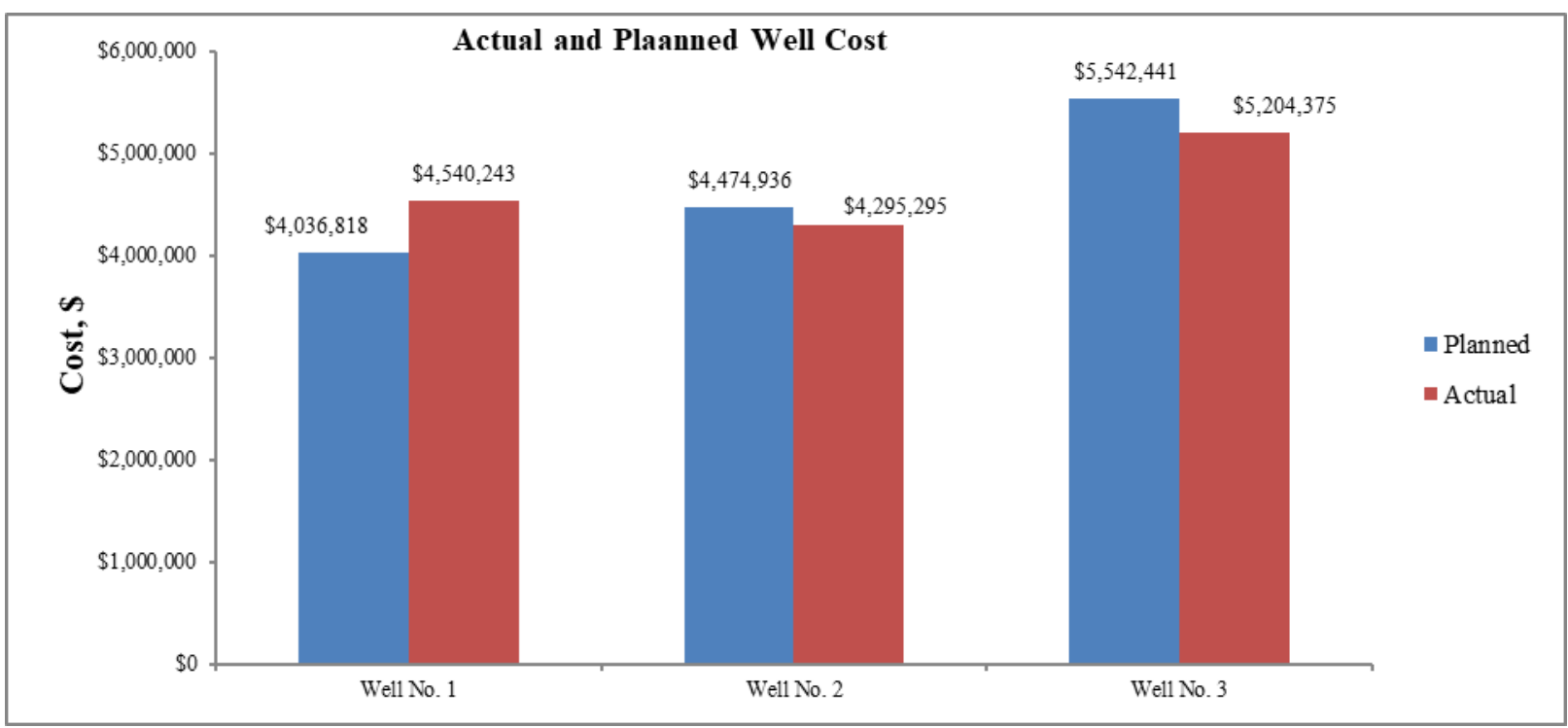

Figure 8 Comparison between Actual and Planned Final Well Cost for Each Well In Field I.

It was obvious that the improper selection of drilling fluids types led to increase the estimated final well cost and for saving thousands, but millions of dollars were spent. Few suggestions were made. These suggestions are:

- Drill problematic formations in this area using oil base drilling fluids as their drilled cuttings are completely not reactive while using oil base fluid.
- Core samples should be obtained from problematic formations, to test the effect of drilling fluid on these formations(Physico-Chemical interaction).

\section{Field II}

This field is an exploratory field located in Sallum area in the Egyptian Western Desert. The formations names, types and litheology are listed in table 4. 
Table 4 Formation Names and Litheology for Field II.

\begin{tabular}{|c|c|}
\hline Formation & Litheology \\
\hline Marmarica & Mainly Limestone \\
\hline Moghra & Sandstone, Claystone and Dolomite \\
\hline Appollonia & Limestone \\
\hline Khoman & Shale and Limestone \\
\hline Abu Roash A & Limestone and Shale \\
\hline Abu Roash B & Shale and Limestone \\
\hline Abu Roash C & Limestone and Shale \\
\hline Abu Roash D & Shale and Limestone \\
\hline Abu Roash E & Limestone and Shale \\
\hline Abu Roash F & Shale and Limestone \\
\hline Abu Roash G & Sandstone, Siltstone and Shale \\
\hline Bahariya & Sandstone, Dolomite and Shale \\
\hline Kharita & Sandstone, Siltstone and Shale \\
\hline Dahab & Dolomite and Limestone \\
\hline Alamein Dolomite & Shale, Limestone, Sandstone and Siltstone \\
\hline Alam El Bueib 1 & Sandstone, Siltstone Shale and Dolomite \\
\hline Alam El Bueib 2 & Shale, Sandstone and Siltstone \\
\hline Alam El Bueib 3A & Siltstone and Shale \\
\hline Alam El Bueib 3C & Sandstone, Siltstone and Shale \\
\hline Alam El Bueib 3G & Siltstone, Sandstone and Shale \\
\hline Alam El Bueib 6 & Limestone, Siltstone and Sandstone \\
\hline Masajid & Shale, Limestone and Siltstone \\
\hline Zahra & Sandstone, Siltstone and Shale \\
\hline Safa & \\
\hline
\end{tabular}

One well was drilled in this area. It was drilled using three main sections and one sidetrack. These sections are 17 1/2", $12 \frac{1}{4} ", 8 \frac{1}{2}$ " and 8 1/2" sidetrack. Spud mud was selected to drill $171 / 2$ " section and top of 12 1/4" section through Marmarica, Moghra, Appollonia formations and Khoman based on its ability to seal permeable formations by building thick filter cake against sand formations and its low cost. $\mathrm{NaCl} / \mathrm{KCl} / \mathrm{PHPA}$ polymer mud was selected due to its ability to inhibit water sensitive shale located in Abu Roash formations. The addition of PHPA and asphaltic materials was to increase mud inhibition ability against shale formations. The production section was $81 / 2 "$. This section was planned to be drilled using high performance water base drilling fluid as the first option, or using oil base drilling fluid as a second option to drill through water sensitive shales in Alam
El Bueib 3G, Alam El Bueib 6 and Zahra formations. The selection was based on linear swelling test result which was made on pre-collected shale cuttings. The test result is represented in figure 9. Three different types of drilling fluids were used. One of these three types had been used in two different compositions. The samples under test swelled in different values and these values are $0.45 \%$ for oil base drilling fluid, $9.55 \%$ to $11.3 \%$ for high performance drilling fluids and $46 \%$ for $\mathrm{KCl}$ polymer mud as shown in figure 9 . Even after the test result, the selection was made to drill with high performance water base drilling fluids as oil base mud requires more cost than water base mud. The occurrences of drilling problems were manifested in figures 10 and 11 .

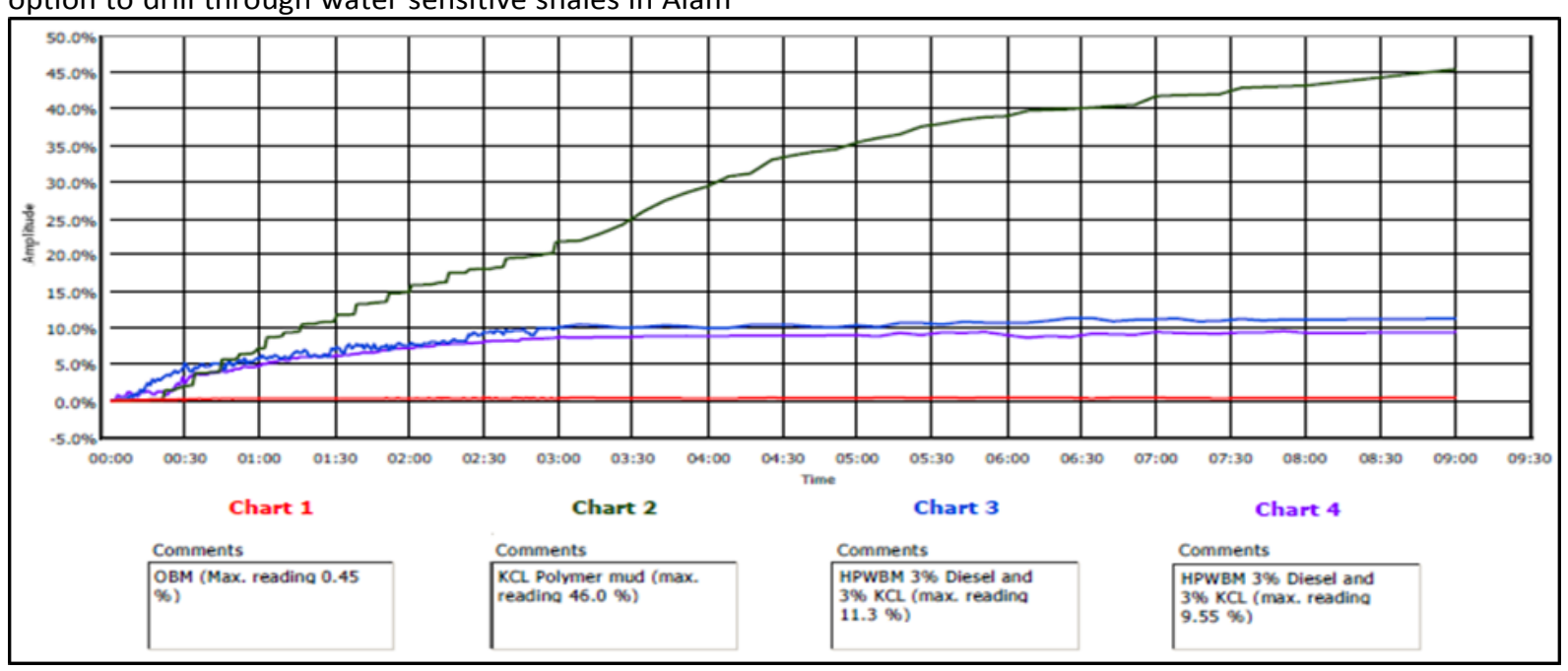

Figure 9 Shows Linear Swelling Test Result for Alam El Bueib 3G Shale in Field II. 


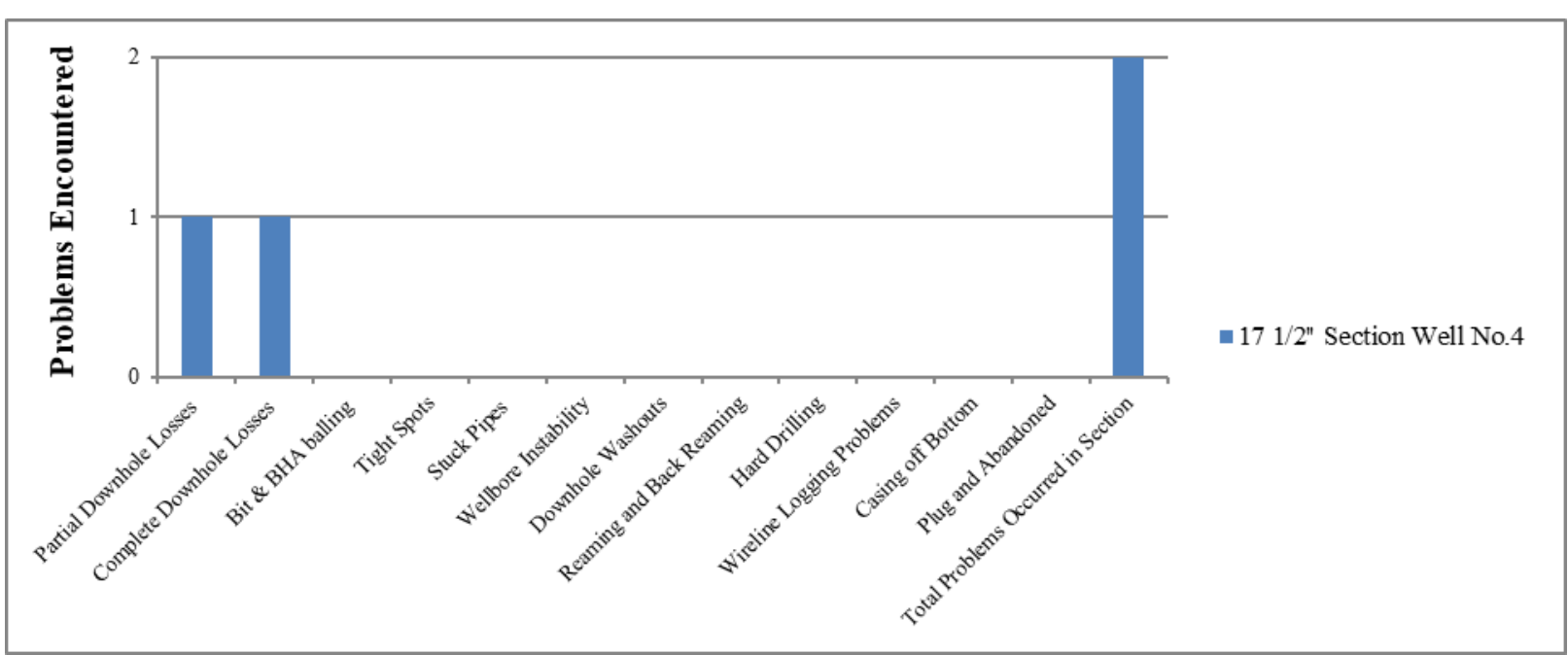

Figure 10 Manifests the Occurrence of the Expected Problems in 17 1/2" Section in Field II.

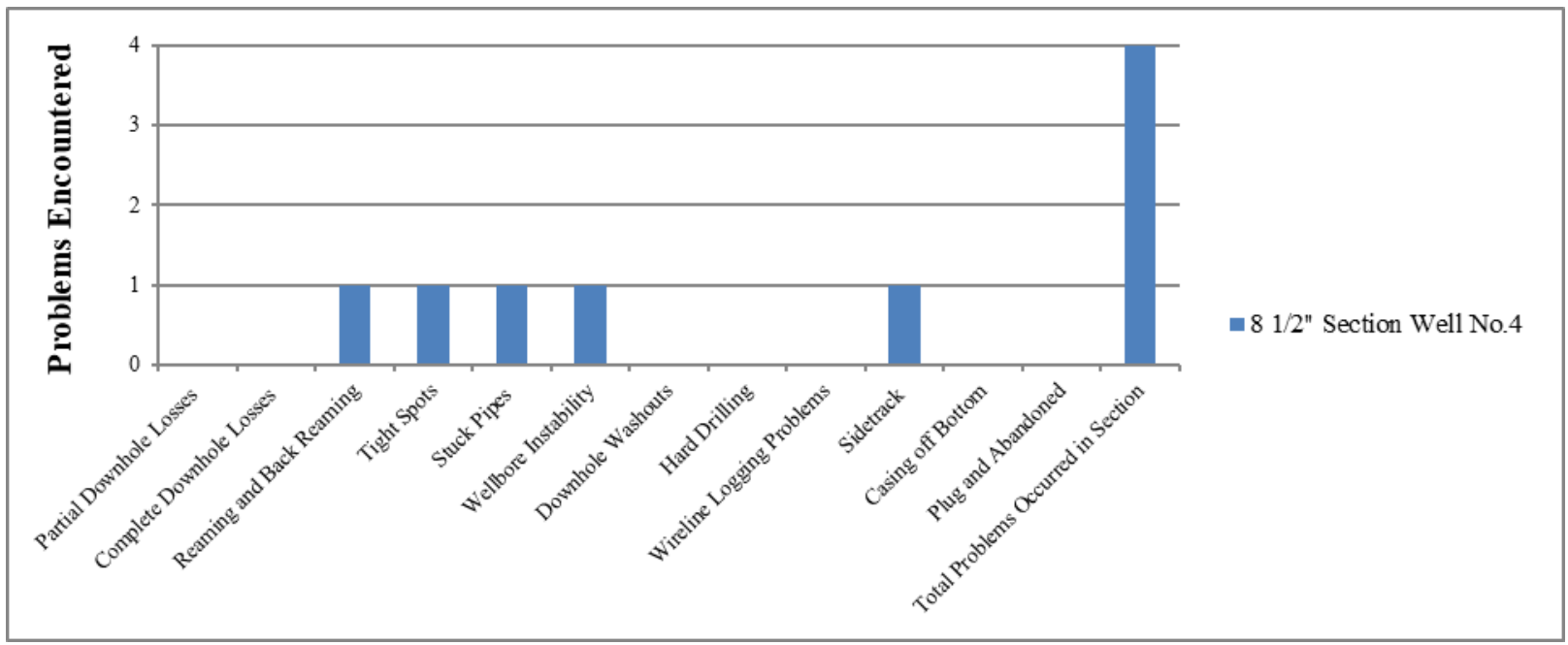

Figure 11 Manifests the Occurrence of the Expected Problems in 8 1⁄2" Section in Field II.

Table 5 Drilling Fluids Types and Their Formulations in Field II.

\begin{tabular}{|l|l|l|l|}
\hline \multicolumn{1}{|c|}{ Product/concentration } & \multicolumn{1}{|c|}{ Spud Mud } & NaCl/3-5 \% KCl Polymer Mud & \multicolumn{1}{c|}{ HPWBDF } \\
\hline Bentonite & $20.0-25.0 \mathrm{ppb}$ & - & - \\
\hline Caustic Soda & $0.5 \mathrm{ppb}$ & $0.5-1.0 \mathrm{ppb}$ & $0.5 \mathrm{ppb}$ \\
\hline Soda Ash & $0.5 \mathrm{ppb}$ & $0.5 \mathrm{ppb}$ & $0.5 \mathrm{ppb}$ \\
\hline Poly Anionic Cellulose LV & - & $3.0 \mathrm{ppb}$ & $4.0 \mathrm{ppb}$ \\
\hline Xanthan Gum & - & $0.25-0.5 \mathrm{ppb}$ & $0.25-0.5 \mathrm{ppb}$ \\
\hline KCl & - & $3.0 \%-5.0 \%$ by wt\% & $3.0 \%-5.0 \%$ by wt\% \\
\hline NaCl & - & $57.0-88.0 \mathrm{ppb}$ & $80 \mathrm{ppb}$ \\
\hline Asphaltic Materials(Shale Stabilizer) & - & $4.0 \mathrm{ppb}$ & $6.0 \mathrm{ppb}$ \\
\hline Starch & - & $5.0 \mathrm{ppb}$ & - \\
\hline PHPA & - & $2.0 \mathrm{ppb}$ & $2.0-3.0 \mathrm{ppb}$ \\
\hline Barite & - & As needed for mud wt & As needed for mud wt \\
\hline Diesel & - & $2.0 \%-3.0 \%$ by V & $5.0-7.0 \%$ by V \\
\hline Polyamine & - & - & $3.0 \%$ by V \\
\hline Sulfonate Materials for HTHP & - & - & $4.0-5.0 \mathrm{ppb}$ \\
\hline Graphitic Materials & - & - & $5.0 \mathrm{ppb}$ \\
\hline Co- Polymers for Shale Inhibition & - & - & $3.0 \%$ by V \\
\hline CaCO & - & - & $5.0-15.0 \mathrm{ppb}$ \\
\hline Thinner & - & - & $2.0 \mathrm{ppb}$ \\
\hline Non Damaging Biodegradable LCM & - & - & If required (2.0-3.0ppb) \\
\hline
\end{tabular}


The last section was $81 / 2 "$ sidetrack which was drilled as a result of wellbore instability problems that were encountered, and led to sidetrack 8 1/2" main hole. Wellbore instability problems were eliminated in sections $81 \frac{1}{2}$ " sidetrack while using oil base drilling fluid. Drilling fluids compositions were presented in tables 5 and 6 . Drilling fluids properties for each section are listed in table 7 .

Cost analysis was made before and after sidetrack as shown in figures 12 and 13. The final well cost was increased due to sidetracking the well as a result of Table 6 Drilling Fluids Types and Their Formulations for Field II. the improper selection of drilling fluid. The difference between water base drilling fluid and oil base drilling fluid in the cost was only $15 \mathrm{k} \$$. This saving in mud cost increased the final well cost to about 590k $\$$. Two results were found

- The selection of drilling fluid type shouldn't be based only on economics, as this could lead to many problems such as losing the hole.

- Drilling fluids are very essential elements in reducing or increasing drilling problems.

\begin{tabular}{|c|c|}
\hline \multicolumn{2}{|l|}{ Drilling Fluid Formulation for OBM 80/20 } \\
\hline Product & Concentration \\
\hline Diesel & $0.62 \mathrm{bbl}$ \\
\hline Water & $0.165 \mathrm{bbl}$ \\
\hline Primary Emulsifier & $0.5-1.0 \mathrm{gpb}$ \\
\hline Secondary Emulsifier & $0.5-1.0 \mathrm{gpb}$ \\
\hline Wetting Agent & $0.15-0.25 \mathrm{gpb}$ \\
\hline Rheology Modifier for LSYP & $0.2-0.4 \mathrm{gpb}$ \\
\hline Organophilic clay as Viscosifier & $5.0-8.0 \mathrm{ppb}$ \\
\hline $\mathrm{CaCl}_{2}$ & $114.0 \mathrm{ppb}$ for $25 \%$ by wt \\
\hline $\mathrm{CaCO}_{3}$ & $10.0-15.0 \mathrm{ppb}$ \\
\hline Barite & As needed to increase mud wt \\
\hline Lime & $5.0-7.0 \mathrm{ppb}$ \\
\hline Amine-Treated Lignite as Filtration Control & $5.0-7.0 \mathrm{ppb}$ \\
\hline
\end{tabular}

Table 7 Drilling Fluids Properties for Each Section in Field II.

\begin{tabular}{|c|c|c|c|c|c|c|c|c|}
\hline \multirow{3}{*}{$\begin{array}{l}\text { Location/Field } \\
\text { Section Name } \\
\text { Property Name }\end{array}$} & \multicolumn{8}{|c|}{ Sallum Area/Field II } \\
\hline & \multicolumn{2}{|c|}{$171 / 2 "$} & \multicolumn{2}{|l|}{$121 / 4^{\prime \prime}$} & \multicolumn{2}{|l|}{$81 / 2 "$} & \multicolumn{2}{|c|}{$81 / 2 " S T$} \\
\hline & Min & Max & Min & Max & Min & Max & Min & $\operatorname{Max}$ \\
\hline Density, ppg & 8.7 & 8.9 & 8.8 & $9.7+$ & 10.1 & 10.45 & 9.6 & 10.15 \\
\hline Funnel Viscosity, sec/quart & 60 & 65 & 55 & 63 & 53 & 94 & 66 & 77 \\
\hline PV, cP & 16 & 18 & 14 & 18 & 14 & 25 & 22 & 26 \\
\hline YP, lbf/100ft ${ }^{2}$ & 25 & 27 & 23 & 25 & 23 & 33 & 21 & 26 \\
\hline $10 \mathrm{sec} / 10 \mathrm{~min}$ Gel, lbf/100ft ${ }^{2}$ & $8 / 14$ & $9 / 15$ & $5 / 9$ & $8 / 15$ & $5 / 7$ & $10 / 14$ & $9 / 15$ & $13 / 19$ \\
\hline API/HTHP Filtrate,cc/30min & $\mathrm{N} / \mathrm{C}$ & $\mathrm{N} / \mathrm{C}$ & 3.2 & $\mathrm{~N} / \mathrm{C}$ & $2.4 / 9.8$ & $3.4 / 14$ & $-/ 5.6$ & $-/ 6.2$ \\
\hline API/HTHP Cake, in/32 & - & - & $1.0 /-$ & $1.0 /-$ & $0.5 / 1.5$ & $0.5 / 2.0$ & $-/ 1$ & $-/ 2.0$ \\
\hline pH & 9 & 9 & 9 & 9 & 9 & 10 & - & - \\
\hline Total Chlorides, mg/l & 700 & 700 & 700 & $115 \mathrm{~K}$ & $123 \mathrm{~K}$ & $150 \mathrm{~K}$ & $3.5 \mathrm{~K}$ & $5.1 \mathrm{~K}$ \\
\hline $\mathrm{KCl}, \mathrm{w} \%$ & - & - & - & 3 & 4 & 4 & - & - \\
\hline MBT, lb/bbl & 22.5 & 22.5 & 7.5 & 22.5 & 5 & 6.25 & - & - \\
\hline Retort Water, \% & 94 & 95 & 89 & 91 & 82 & 88 & 18 & 19 \\
\hline Retort Oil, \% & - & - & - & - & - & 3 & 68 & 68 \\
\hline Retort Solids, \% & 5 & 6 & 9 & 11 & 12 & 16 & 13 & 14 \\
\hline Pom, cc & - & - & - & - & - & - & 3.5 & 4.7 \\
\hline O/W Ratio, \% & - & - & - & - & - & - & $78 / 22$ & $79 / 21$ \\
\hline E.S., volts & - & - & - & - & - & - & 600 & 770 \\
\hline
\end{tabular}




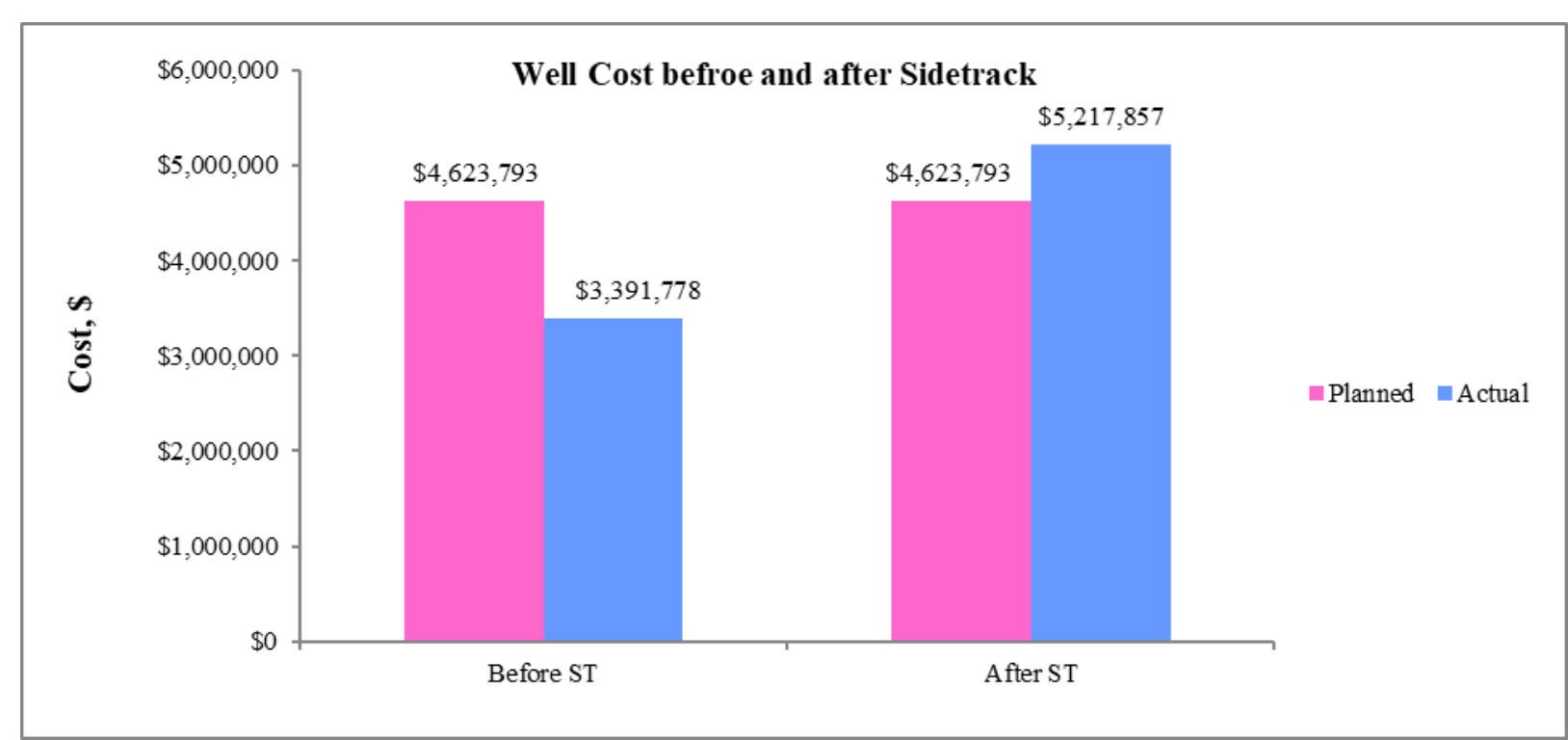

Figure 12 Comparison between Actual and Planned Final Well Cost before and after Sidetrack in Field II.

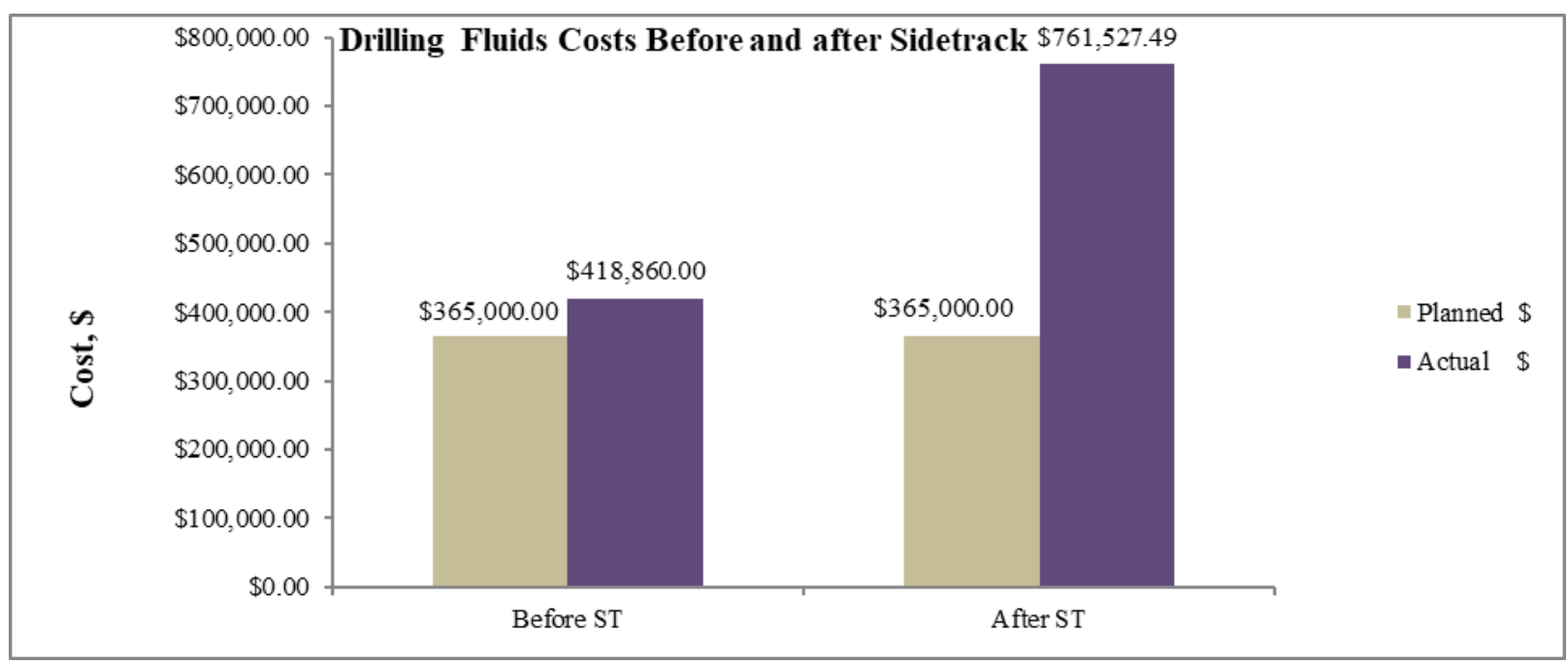

Figure 13 Comparison between Actual and Planned Drilling Fluids Cost before and after Sidetrack in Field II.

\section{Field III}

This field is a production field located in South of Marsa Matrouh area in the Egyptian Western Desert. The formations names, types and litheology are listed in table 8.

Table 8 Formation Names and Litheology for Field III.

\begin{tabular}{|c|l|}
\hline \multicolumn{1}{|c|}{ Formation } & \multicolumn{1}{|c|}{ Litheology } \\
\hline \multicolumn{1}{|c|}{ Marmarica } & Sandstone, Limestone and Clay \\
\hline Dabaa & Sandstone, Limestone and Shale \\
\hline Appollonia & Shale \\
\hline \multicolumn{1}{|c|}{ Khoman } & Chalky Limestone \\
\hline Abu Roash A & Limestone and Shale \\
\hline Abu Roash B & Limestone \\
\hline Abu Roash C & Limestone \\
\hline Abu Roash D & Limestone \\
\hline Abu Roash E & Limestone and Shale \\
\hline Abu Roash F & Limestone \\
\hline Abu Roash G & Shale and Limestone \\
\hline Bahariya & $\begin{array}{l}\text { Sandstone, Siltstone, Limestone } \\
\text { and Shale }\end{array}$ \\
\hline
\end{tabular}

Five wells were selected in this study. These wells were drilled in two sections $121 / 4$ " and $81 / 2 "$. The first sections were $121 / 4$ " surface sections which were drilled using spud mud to the bottom of Moghra which contain shale and then the wells were displaced to $\mathrm{NaCl} / 3-5 \% \mathrm{KCl}$ polymer mud to drill bottom of Moghra and water sensitive shale in Dabaa formation to the top of Appollonia formation which is the casing point for that section. The second sections were $81 / 2 "$ sections drilled with spud mud preserved from 12 1/4" to drill Appollonia, Khoman and top of Abu Roash A formations and at the top of Abu Roash A formation the wells were displaced to $\mathrm{NaCl} / 3-5 \% \mathrm{KCl}$ polymer mud to drill through Abu Roash formations members and Bahariya formation which is the wells target. $\mathrm{KCl}$ salt was used in three wells as a shale inhibition. $\mathrm{NaCl}$ polymer mud was used and loaded with 5-7\% Diesel in the other two wells without any $\mathrm{KCl}$ salt. Drilling fluids compositions and properties were listed in tables 9 and 10 .

Figures 14 and 15 manifest the problems that were encountered in each section in every well. Cost analysis was made as shown in figures 16 and 17 . It can be seen from the figures that the final well cost was the lowest even with a higher drilling fluids cost 
than other wells, so that controlling drilling fluids cost will not lead to reduce the final well cost. This unstudied reduction in drilling fluids costs could lead to increase the final well cost.

Results that could be obtained from the above discussion are:

- The drilling fluid that reduces drilling problems should be used in field III.

Table 9 Drilling Fluids Compositions for Field III.
- Spud mud should be treated with lime to reduce hole washouts in Khoman formation.

- Oil base drilling fluid could be used to drill water soluble formations with respect to other factors while selecting drilling fluid types.

\begin{tabular}{|c|c|c|}
\hline \multicolumn{3}{|l|}{ Drilling Fluid Formulation for WBM } \\
\hline Product/concentration & Spud Mud & $\mathrm{NaCl} / 3-5 \% \mathrm{KCl}$ Polymer mud \\
\hline Bentonite & $30.0-35.0 \mathrm{ppb}$ & - \\
\hline Caustic Soda & $0.5 \mathrm{ppb}$ & $0.5 \mathrm{ppb}$ \\
\hline Soda Ash & $0.5 \mathrm{ppb}$ & $0.5 \mathrm{ppb}$ \\
\hline Poly Anionic Cellulose LV & - & $1.0-2.0 \mathrm{ppb}$ \\
\hline Xanthan Gum & - & $0.5 \mathrm{ppb}$ \\
\hline KCL & - & $5.0 \%-7.0 \%$ by wt\% \\
\hline $\mathrm{NaCL}$ & - & $80.0 \mathrm{ppb}$ \\
\hline Asphaltic Materials (Shale Stabilizer) & - & If needed $4.0 \mathrm{ppb}$ \\
\hline Starch & - & $2.0-4.0 \mathrm{ppb}$ \\
\hline PHPA & - & $2.0 \mathrm{ppb}$ \\
\hline Barite & - & If needed mud wt \\
\hline Diesel & - & $5 \%-10 \%$ by $V$ \\
\hline $\mathrm{CaCO}_{3}$ & - & $10-15 \mathrm{ppb}$ \\
\hline Non Damaging Biodegradable LCM & - & $3 \mathrm{ppb}$ If needed \\
\hline
\end{tabular}

Table 10 Drilling Fluids Properties for each Section in Field III.

\begin{tabular}{|c|c|c|c|c|}
\hline \multirow{3}{*}{$\begin{array}{l}\text { Location/Field } \\
\text { Section Name } \\
\text { Property Name }\end{array}$} & \multicolumn{4}{|c|}{ South of Marsa Matrouh Area/Field III } \\
\hline & \multicolumn{2}{|l|}{$121 / 4 "$} & \multicolumn{2}{|l|}{$81 / 2 "$} \\
\hline & Min & Max & Min & Max \\
\hline Density, ppg & 8.7 & $9.7+$ & 8.7 & 9.8 \\
\hline Funnel Viscosity, sec/quart & 47 & 90 & 44 & 80 \\
\hline PV, cP & 10 & 18 & 10 & 25 \\
\hline YP, Ibf/100ft ${ }^{2}$ & 18 & 50 & 15 & 28 \\
\hline $10 \mathrm{sec} / 10 \mathrm{~min}$ Gel, $\quad \mathrm{lbf} / 100 \mathrm{ft}^{2}$ & $4 / 6$ & $25 / 35$ & $4 / 5$ & $13 / 17$ \\
\hline API/HTHP Filtrate, $c c / 30 \mathrm{~min}$ & $2.9 /-$ & $\mathrm{N} / \mathrm{C}$ & $2.4 /-$ & $\mathrm{N} / \mathrm{C}$ \\
\hline API/HTHP Cake, in/32 & $0.5 /-$ & $2.0 /-$ & $0.5 /-$ & $2.0 /-$ \\
\hline Ph & 8 & 10 & 9 & 10 \\
\hline Total Chlorides, $\mathrm{mg} / \mathrm{l}$ & $1.7 \mathrm{~K}$ & $132 \mathrm{~K}$ & $25 \mathrm{~K}$ & $141 \mathrm{~K}$ \\
\hline $\mathrm{KCl}, \mathrm{w} \%$ & - & 5 & - & 3 \\
\hline MBT, lb/bbl & 5 & 30 & 2.5 & 30 \\
\hline Retort Water, \% & 80 & 96 & 77 & 92 \\
\hline Retort Oil, \% & - & 7 & - & 7 \\
\hline Retort Solids, \% & 6 & 14 & 8 & 16 \\
\hline
\end{tabular}




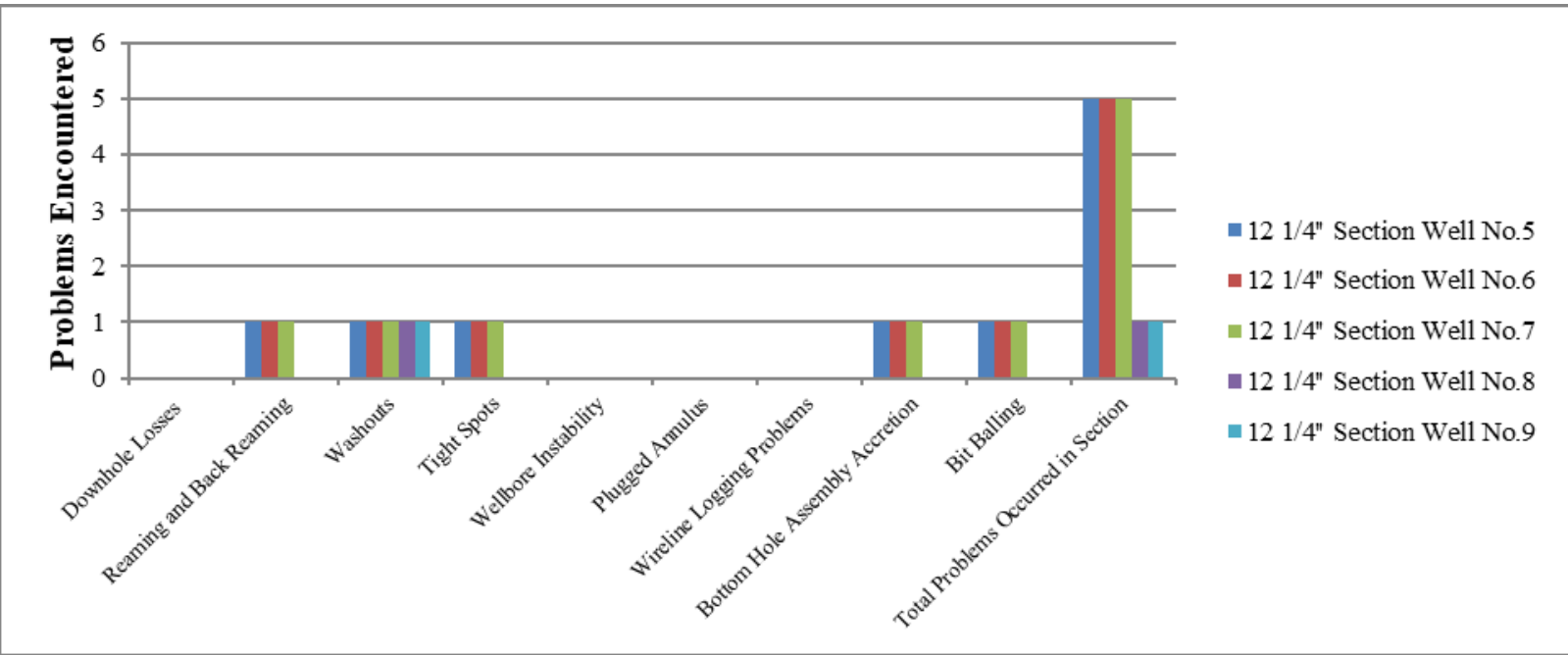

Figure 14 Manifests the Occurrence of Expected Problems while Drilling 12 1/4" Sections in Field III.

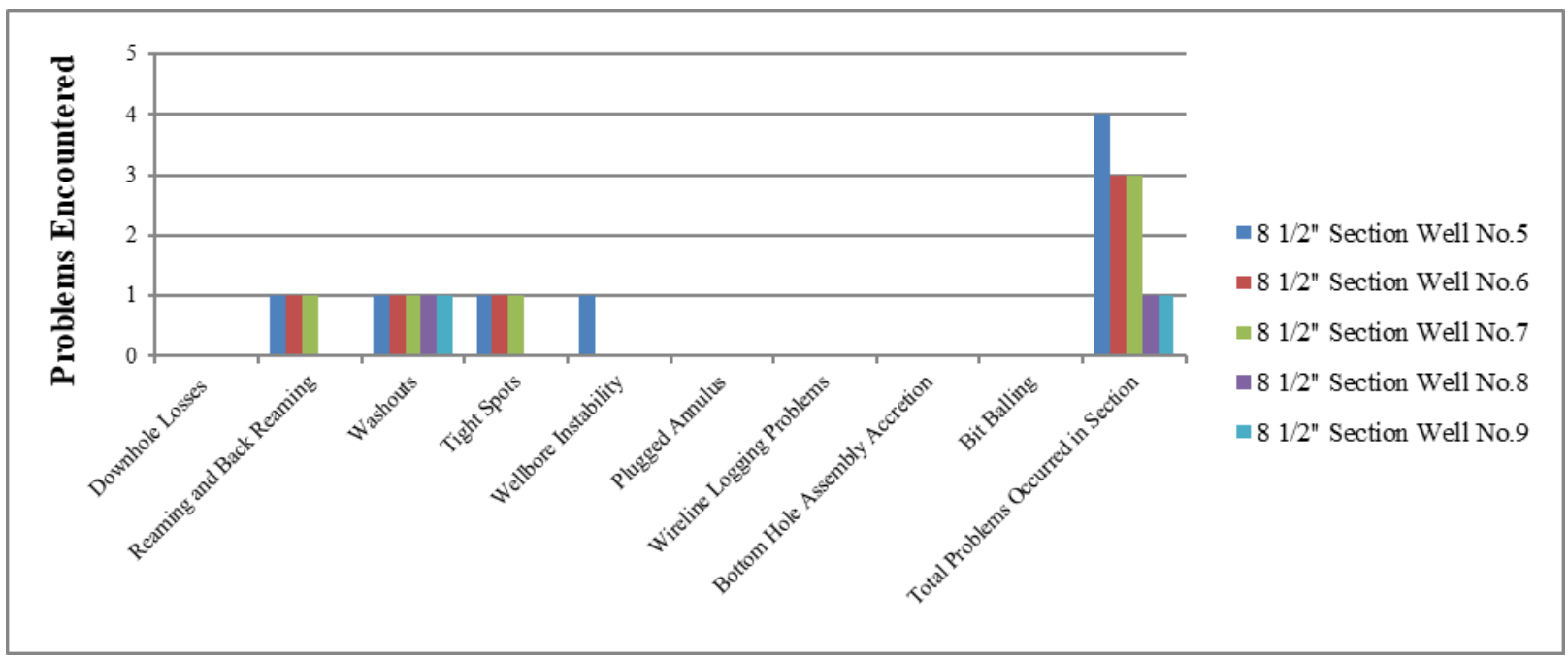

Figure 15 Manifests the Occurrence of Expected Problems while Drilling 8 1⁄2" Sections in Field III.

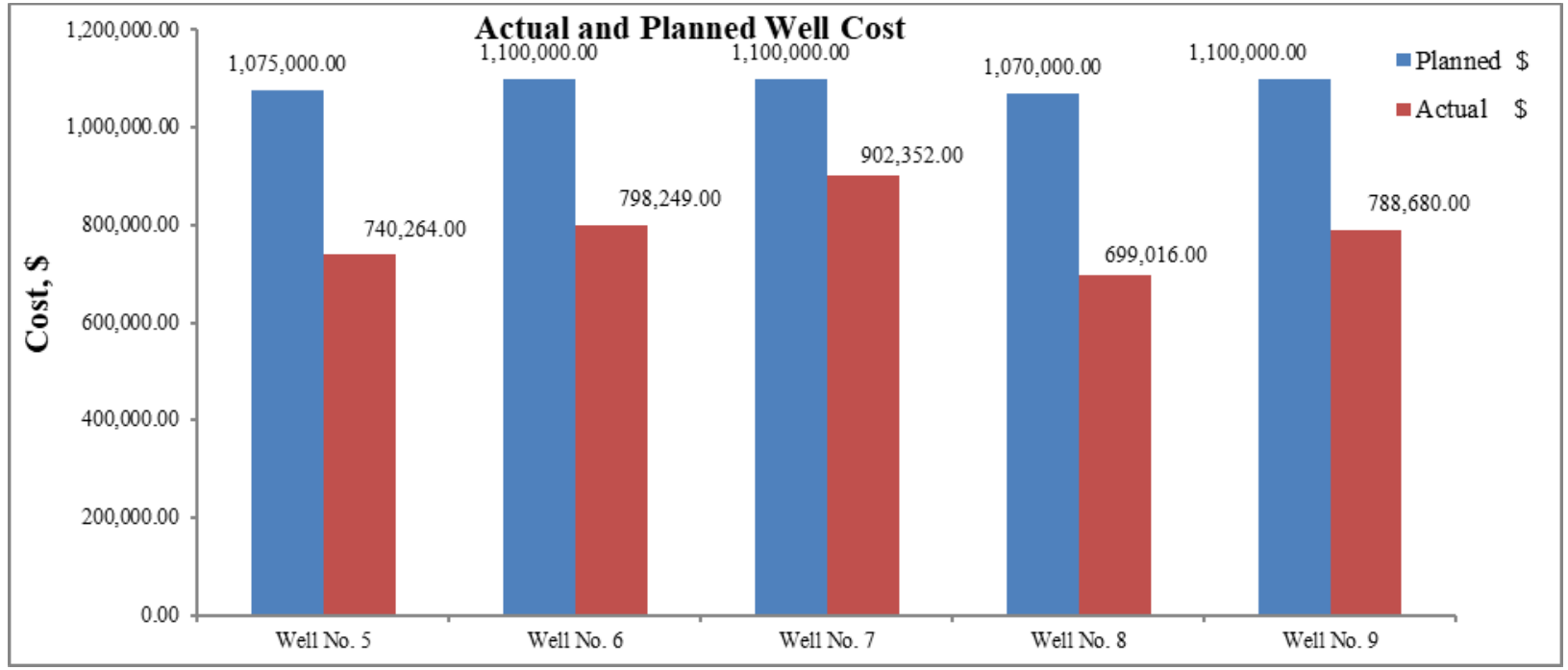

Figure 16 Comparison between Actual and Planned Final Wells Cost for Five Wells in Field III.

\section{Conclusions}

Based on the above discussion the following conclusions could be obtained:

- Core samples should be obtained from problematic formations, to test the effect of drilling fluid on these formations.
- Oil base drilling fluid should be used in exploratory wells to drill problematic formations.

- Cost reduction in drilling fluid cost should be studied carefully, to avoid problems that might result from that deduction.

- The improper selection of drilling fluid types could lead to a lot of well problems that can end with complete well abandonment. 
- Even with the proper selection of drilling fluid types the design of their characteristics plays a major role in completing the well.

- The type of drilling fluid shouldn't be selected based on back experience and economics only, the other factors should be considered as well.

- The drilling fluid that reduces drilling problems should be used in field III.

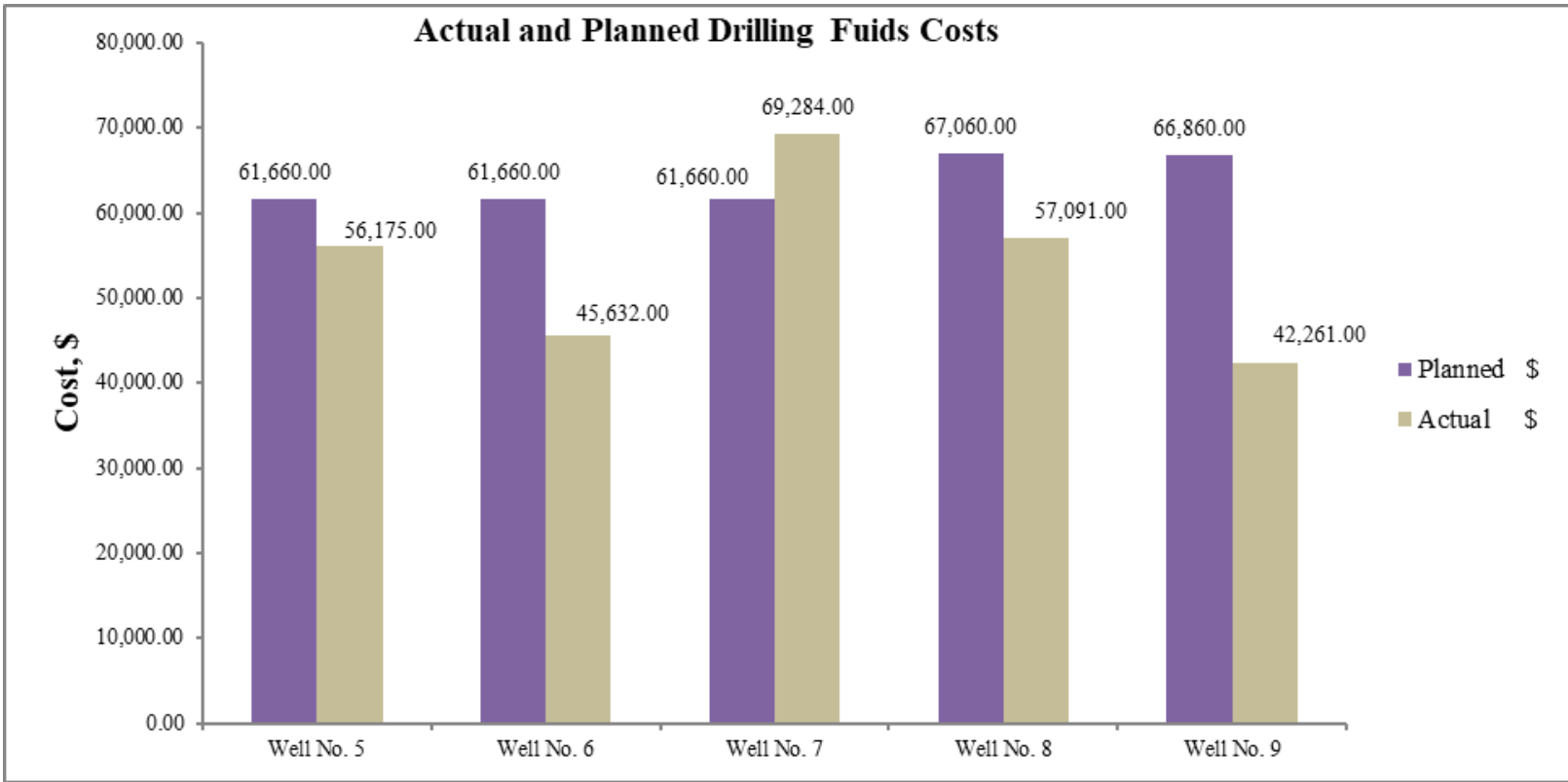

Figure 17 Comparison between Actual and Planned Drilling Fluids Costs for Five Wells in Field III.

\section{Nomenclature}

$\mathrm{CaCO}_{3}=$ Calcium Carbonate.

$\mathrm{cc}=$ Cubic Centimeter.

E.S. = Electric Stability.

$\mathrm{K}=$ Thousands

$\mathrm{KCl}=$ Potassium Chloride Salt.

$\mathrm{MBT}=$ Methylene Blue Test.

$\mathrm{NaCl}=$ Sodium Chloride Salt.

$\mathrm{N} / \mathrm{C}=$ Not Controlled.

$\mathrm{O} / \mathrm{W}=$ Oil/Water Ratio.

PHPA = Partially Hydrolysed Polyacrylamide.

Pom = Mud Alkalinity for Oil Base Mud.

ppb = Pound per Barrel.

$\mathrm{PV}=$ Plastic Viscosity

$\mathrm{XRD}=\mathrm{X}$ - Ray Diffraction.

YP $=$ Yield Point.

\section{Reference}

[1] Bourgoyne, A. T., Chenevert, M. E., Millheim, K. K. and Young, F. S.: Applied Drilling Engineering, SPE Textbook Series, Vol. 2, Second printing, SPE, Richardson, TX, 1991, pp 41- 84

[2] Khodja, M., Khodja-Saber, M., Canselier, J. P., Cohaut, N. and Bergaya, F.: “Drilling Fluid Technology: Performances and Environmental Considerations," Products and Services; from R and D to Final Solutions, Igor Fuerstner (Ed.), ISBN: 978-953-307-211-1, InTech, 2010.

[3] Darley, H. C. H and Gray, G. R.: Composition and Properties of Drilling and Completion Fluids, published
- Spud mud should be treated with lime to reduce hole washouts in Khoman formation.

- Oil base drilling fluid could be used to drill water soluble formations with respect to other factors while selecting drilling fluid types.

- Drilling fluids are very essential elements in reducing or increasing drilling problems. 